\title{
The Effects of Brand Image and Product Quality on Purchase Decisions
}

\author{
Novita Rosanti ${ }^{*}$ Karta Negara Salam, Panus \\ Faculty of Economics and Business, Institut Bisnis dan Keuangan Nitro, Makassar, Indonesia,
}

\begin{abstract}
The study aim is to analyze Are brand image and product quality partially positive and significant impact on purchasing decisions at Starbuck; Do brand image and product quality simultaneously have a positive and significant effect on purchasing decisions at Starbucks; Which variable has the most dominant influence on purchasing decisions at Starbucks. In this study, the authors chose the research location in Starbucks, Trans Studio Mall, Makassar City. In connection with the problems previously stated, an analysis will be carried out based on the data obtained using the following calculation: (1) Validity test, used to measure whether a questionnaire is valid or not. A questionnaire is said to be useful if the questionnaire's questions can reveal something, which is measured by the questionnaire. The results showed that the brand image variable had positive and significant influences on purchasing decisions; this indicated that Starbucks should maintain a good brand reputation, increasing consumer loyalty. Introducing products to consumers will give a good impression, and consumers will also remember the product. The results showed that the product quality variable had positive and significant effects on purchasing decisions; this indicated that Starbucks had to improve the quality of the products offered to increase sales levels. $12.9 \%$ of variables are not examined in this thesis, and this also affects the purchasing decision at Starbucks Trans Studio Mall Makassar; the variables that are not examined are (Price, Location, and Lifestyle). Researched, so you can find out what variables influence a person to make purchasing decisions at Starbucks Trans Studio Mall Makassar. In this study, the authors chose the research location in Starbucks, Trans Studio Mall, Makassar City. In connection with the problems previously stated, an analysis will be carried out based on the data obtained using the following comment: (1) Validity test, used to measure whether a questionnaire is valid or not. A questionnaire is said to be useful if the questionnaire's questions can reveal something, which is measured by the questionnaire. The results showed that the brand image variable had positive and significant effects on purchasing decisions; this indicated that Starbucks should maintain a good brand reputation, increasing consumer loyalty. Introducing products to consumers will give a good impression, and consumers will also remember the product. The results showed that the product quality variable had positive and significant influences on purchasing decisions; this indicated that Starbucks had to improve the quality of the products offered to increase sales levels. $12.9 \%$ of variables are not examined in this thesis, and this also affects the purchasing decision at Starbucks Trans Studio Mall Makassar, the variables that are not examined are (Price, Location, and Lifestyle). Researched, so you can find out what variables influence a person to make purchasing decisions at Starbucks Trans Studio Mall Makassar.
\end{abstract}

Keywords: Brand image; product quality; purchase decision.

\section{Introduction}

In today's business world, the level of competition between industries is getting tighter, including companies in Indonesia, Indonesia as a developing country cannot be separated from the development of its business industry, one of which is the increasing number of coffee shops that are mushrooming, both coffee shops. Local or abroad that also enliven the coffee shop industry in Indonesia, each coffee shop company competes to improve its quality to compete with other coffee shops by enhancing its quality to become an attraction for consumers later. The culinary business in coffee shops has expanded its function. In the past, coffee shops were only an answer to the community's needs for coffee consumption and socializing. In today's world, coffee shops have increased their function to support work activities, a place to seek self-recognition, and a place for socializing (Ramlawati et al., 2019).

In Indonesia, the Dutch cultivated coffee during the period of forced cultivation from 1830 to 1870 to be traded. In

\footnotetext{
* Corresponding author.

E-mail address: n.rosanti.nr@gmail.com
} 
2016, Indonesia became the world's 4th largest coffee producer with a production output of 11,491,000 tons. The number of coffee production can be so large because almost all islands in Indonesia the coffee plant in Indonesia is 1.24 million hectares consisting of 933 thousand hectares of robusta plantations and 307 hectares of arabica plantations, and local farmers manage more than $90 \%$ of the land with total land area. An average of 1-2 hectares tonnes (www.indonesia-investments.com, 2017). Starbucks corporation is a coffee company and global coffee shop chain from the United States headquartered in Seattle, Washington. In Indonesia, the Starbucks coffee chain is operated by PT Mitra Adiperkasa Tbk. Starbucks is already present in 12 cities in Indonesia with more than 150 outlets (Starbucks.co.id, 2018). The menus sold at Starbucks include coffee, tea, and accompanying cakes. On September 27, 2012, Starbucks Indonesia was named one of the Top 10 Brands in Indonesia by The Nielsen Company and Campaign Asia Pacific's Asia's Top 1000 Brands report with a ranking of 10. (swa.co.id, 2012)

Product quality is prioritized in business. Regardless, according to (Kotler et al., 2013; Ma et al., 2020; Yoon C. Cho, 2015; Zhu et al., 2020), product quality is the ability of a product to demonstrate its function; this includes overall durability, accuracy, ease of operation, and product repair, as well as other product attributes. In improving the quality of its products, Starbucks is very selective in choosing coffee beans; based on the official Starbucks website (www.Starbucks.co.id, 2018), Starbucks only decides on coffee beans grown in the highlands because, in the highlands, the coffee beans will become denser. And has a more pungent taste; only the selected coffee cherries are red and meet the standard. Product quality is defined as the totality of product features and characteristics defined as the totality of features and characteristics of a product or service that can satisfy stated or implemented needs (Zhu et al., 2020). Image of Brand is a concept that is easy to understand but difficult to explain systematically because of its abstract nature; the image of the brand is related to attitudes in the form of beliefs and preferences for brands related to attitudes in the form of thoughts and intentions for a brand (Halkias et al., 2017; Huang \& Liu, 2020; Kim \& Yoo, 2015; Maheshwari \& Yadav, 2015; Sondakh, 2015). Based on the above background, the problem formulation will be discussed in this study, namely:

1. Our brand image and product quality partially positive and significant impact on purchasing decisions at Starbucks?

2. Do brand image and product quality simultaneously have a positive and significant effect on purchasing decisions at Starbucks?

3. Which variable has the most dominant influence on purchasing decisions at Starbucks?

\section{Methodology}

In this study, the authors chose the research location in Starbucks, Trans Studio Mall, Makassar City. The time needed in this study is approximately one month. The population in this study were Starbucks consumers during the last year, amounting to 54,700 people. The sample of this study was determined using the Slovin formula, which according to (Ghozali, 2013; Rudolph et al., 2019), namely:

where:

$$
n=\frac{N}{(N . e)+1}
$$

$$
\begin{array}{ll}
\mathrm{n} & =\text { sample size } \\
\mathrm{N} & =\text { population size } \\
\mathrm{e} & =\text { leeway inaccuracy due to tolerated sampling errors. }
\end{array}
$$

This tolerable error limit for each population is not the same. In this study, it was used at $10 \%$. While the use of the formula above assumes that the population is normally distributed. Based on the formula above, the number of samples from the population is 100 respondents. The data collection technique used in this study was through a questionnaire. The questionnaire is a data collection technique done by giving a set of questions or written questions to the respondent to answer. Library Research is also carried out in this research in the form of theoretical or conceptual materials obtained from the internet and libraries in the form of literature and scientific articles/journals that can support research studies and analyze problems. Field research using questionnaires (Questionnaire), in which the author distributes a written questionnaire containing a list of questions to customers selected as respondents and 
uses a closed list of questions, namely questions that have been provided with the possibility of an answer first and the respondent does not have the opportunity to offer other solutions. Interviews were conducted directly between respondents and researchers to obtain information relevant to the research objectives and obtain information with the highest possible validity and reliability. This type of research uses a quantitative methodology. With this quantitative method, it is hoped that researchers can explain the behavior of consumer and customer purchasing decisions. The data source used in this research is primary data. Primary data in this study are data obtained directly from questionnaires to Starbucks customers. External secondary data is obtained through books, journals, references, and articles related to research topics, to acquire theoretical knowledge and expert opinion related to this research so that it can help analyze the problem under study (Garson, 2016; Lee et al., 2001) The method of analysis used in this study is a quantitative method, where this method tries to process data in the form of information into numbers. For data processing in this study using SPSS 20. In addition to calculating data using validity tests, reliability tests, multiple liner tests, F test, and t-test. Data analysis in the data processing process and interpreting the results of processing through inferential analysis emphasizes the relationship between variables by testing hypotheses and concluding the study results (Sugiyono, 2014)

In connection with the problems previously stated, an analysis will be carried out based on the data obtained using the following comment: (1) Validity test, used to measure whether a questionnaire is valid or not. A questionnaire is said to be useful if the questions on the questionnaire can reveal something. Which is measured by the questionnaire. The validity test is calculated by comparing the value of the $\mathrm{r}$ count (correlation item-total correlation) with the $\mathrm{r}$ table's value. If $r$ count $>r$ table and the value is positive, then the question is declared valid. (2) A reliability test is data to measure a questionnaire which is an indicator of a variable. A questionnaire is reliable or reliable if a person's answer to a question is consistent or stable over time. Reliability concerning the consistency of responses if tested repeatedly on different samples.SPSS provides facilities to measure reliability with the Cronbach Alpha (a) statistical test. A variable is said to be reliable if it gives a Cronbach Alpha value> 0.60. (3) Multiple Linear Regression Test, inferential statistical analysis techniques are performed using multiple linear regression analysis. Multiple linear analysis is useful in estimating the dependent variable's value using more than one independent variable. The multiple linear regression equation is as follows:

$$
\mathrm{Y}=\mathrm{a}+\mathrm{b} 1 \mathrm{X} 1+\mathrm{b} 2 \mathrm{X} 2+\mathrm{e}
$$

$\begin{array}{cl}\text { where: } & \\ \text { Y } & =\text { Purchase decision } \\ \mathrm{X} 1 & =\text { Brand image } \\ \mathrm{X} 2 & =\text { Product quality } \\ \mathrm{a} & =\text { Constant value } \\ \mathrm{b} & =\text { Regression coefficient } \\ \mathrm{e} & =\text { Standard Error }\end{array}$

The t-test is carried out to test the significant influence of the independent variable's impact (independent variable) on the dependent variable (bound). The t-test aims to partially test the independent variable on the dependent variable, with the Sig test criteria. $T \leqslant a$, it is stated that there is a partial and significant effect. The test criteria for the t-test uses a significance of 0.005 and 2 sides with the following hypothesis (Sarwono, 2012):

$\mathrm{H}_{0}$ : There is no effect of the independent variable on the dependent variable.

$\mathrm{H}_{\mathrm{a}}$ : There is an effect of the independent variable on the dependent variable.

Another calculation uses the $\mathrm{t}$ table, were criteria in t-test testing, namely: (Field et al., 2013). If $\mathrm{t}<\mathrm{t} \alpha / 2$, then Ho is accepted. So, $\mathrm{H}_{\mathrm{a}}$ is rejected and bi $=0$, meaning that the variable Xi does not affect $\mathrm{Y}$. If $\mathrm{t}>\mathrm{t} \alpha / 2$, then Ho is rejected. So, $\mathrm{H}_{0}$ is accepted and bi $\neq 0$, meaning that the variable $\mathrm{Xi}$ influences $\mathrm{Y}$. The $\mathrm{F}$ test results from multiple linear calculations will get the parameters $\mathrm{F}$ and Adjusted $\mathrm{R}$ Square. If the regression is significant at $\mathrm{F}<0.05$, it means that the independent variable has a significant effect on the dependent variable. Adjusted R Square shows the model's ability to explain variations in the dependent variable. The greater the Adjusted R Square, the better the model can explain the dependent variable's variation. The coefficient of determination in linear regression is often defined as all independent variables' ability to explain the variance of the dependent variable. In simple terms, the coefficient of 
determination is calculated by squaring the Correlation Coefficient $(\mathrm{R})$. For example, if the value of $\mathrm{R}$ is 0.80 , the coefficient of determination ( $\mathrm{R}$ Square) is $0.80 \times 0.80=0.64$. It means that the independent variable's ability to explain the dependent variable's variance is $64.0 \%$. It means a $36 \%(100 \%-64 \%)$ variance of the dependent variable, explained by other factors. Based on this interpretation, it appears that the value of $\mathrm{R}$ Square is between 0 and 1.

Table 1. Operational Variable Research

\begin{tabular}{|c|c|c|}
\hline Variables & Operational Definition & Indicators \\
\hline Brand Image (X1) & $\begin{array}{l}\text { Consumer perceptions about a brand as a } \\
\text { reflection of the brand association that } \\
\text { exists in the minds of the consumer }\end{array}$ & $\begin{array}{ll}- & \text { Recognition } \\
\text { - } & \text { Reputation } \\
\text { - } & \text { Affinity } \\
\end{array}$ \\
\hline $\begin{array}{l}\text { Product } \\
\text { (X2) }\end{array}$ & $\begin{array}{l}\text { Is the ability of a product to satisfy } \\
\text { consumers seen from the overall } \\
\text { characteristics of the product }\end{array}$ & $\begin{array}{ll}- & \text { Form } \\
\text { - } & \text { Taste } \\
\text { - } & \text { Color } \\
\text { - } & \text { appearance } \\
\text { - } & \text { designs } \\
\end{array}$ \\
\hline $\begin{array}{l}\text { Purchasing decision } \\
\text { (Y) }\end{array}$ & $\begin{array}{l}\text { A series of processes carried out by } \\
\text { consumers before and after buying a } \\
\text { product, both in the form of goods and } \\
\text { services }\end{array}$ & $\begin{array}{l}\text { - Purchase decisions due to needs \& } \\
\text { wants. } \\
\text { - Purchase decisions are based on the } \\
\text { information and related sources. } \\
\text { - Purchase decision after making an } \\
\text { assessment. } \\
\text { - Get a product. }\end{array}$ \\
\hline
\end{tabular}

\section{Results and Discussion}

\subsection{Characteristics of Respondents}

Respondents in this study were Starbucks customers with respondent characteristics based on gender, age, and occupation. To clarify the characteristics of the respondents in question, a table regarding the following respondents is presented:

Table 2. Gender, age, and occopation of respondents

\begin{tabular}{ccc}
\hline Gender & Total & Percentage \\
\hline Male & 59 & $59,0 \%$ \\
Female & 41 & $41,0 \%$ \\
\hline Total & $\mathbf{1 0 0}$ & $\mathbf{1 0 0 \%}$ \\
\hline & & Percentage \\
\hline Age & Total & $25,0 \%$ \\
$22-30$ & 25 & $30,0 \%$ \\
$30-40$ & 30 & $33,0 \%$ \\
$>40$ & 33 & $12,0 \%$ \\
\hline Total & 12 & $\mathbf{1 0 0 , 0 \%}$ \\
\hline & $\mathbf{1 0 0}$ & \\
\hline Occupation & & Percentage \\
\hline Students & Total & $30,0 \%$ \\
Civil Servants & 30 & $16,0 \%$ \\
Employers & 16 & $36,0 \%$ \\
Private Employees & 36 & $18,0 \%$ \\
\hline Total & 18 & $\mathbf{1 0 0 \%}$
\end{tabular}

Based on the table 2, it can be seen the gender of these respondents is the same in number per category, namely male 
59 respondents and female respondents total 41 respondents. Male visitors have the highest percentage of coffee drinkers because, on average male visitors. The age of the respondents varied, therefore the researcher categorized it into four categories, and from the results of the research, it was known that the number of respondents whose age was $<22$ years was 25 respondents, the age category of 22-30 years was 30 respondents, and in the 30-40 year age category. Totaled 33 respondents, and types> 40 years amounted to 12 respondents. Ages 30-40 have the highest percentage because many Starbucks visitors are office employees. The respondent's work is varied. Therefore the researcher categorizes it into four categories, and the results of the research show that the number of respondents who have student/student jobs is 30 respondents, those who have civil servant jobs are 16 respondents, who have entrepreneurial jobs totaling 36 respondents, and have private employee jobs totaling 18 respondents. Because Starbucks customers are mostly students and entrepreneurs. Entrepreneurs have the highest percentage; the reason is that many entrepreneurs hold meetings that discuss work or meet clients.

\subsection{Descriptive Results Analysis}

Descriptive analysis of the results is used as a summary of the data to determine the respondents' answers to each statement contained in the research instrument. Description of Variable Brand Image (X1).

Table 3. Respondents' Responses Regarding Brand Image

\begin{tabular}{|c|c|c|c|c|c|c|c|c|c|c|}
\hline \multirow{3}{*}{ Statement } & \multicolumn{10}{|c|}{ Respondents' Answers } \\
\hline & \multicolumn{2}{|c|}{ STS } & \multicolumn{2}{|c|}{ TS } & \multicolumn{2}{|c|}{$\mathrm{KS}$} & \multicolumn{2}{|c|}{$\mathrm{S}$} & \multicolumn{2}{|c|}{ SS } \\
\hline & $\mathrm{N}$ & $\%$ & $\mathrm{~N}$ & $\%$ & $\mathrm{~N}$ & $\%$ & $\mathrm{~N}$ & $\%$ & $\mathrm{~N}$ & $\%$ \\
\hline $\begin{array}{l}\text { Starbucks is a well-known coffee company } \\
\text { that has gone global }\end{array}$ & 0 & 0 & 0 & 0 & 1 & 1,0 & 38 & 38,0 & 61 & 61,0 \\
\hline Starbucks has good quality coffee. & 0 & 0 & 0 & 0 & 0 & 0 & 40 & 40,0 & 60 & 60,0 \\
\hline $\begin{array}{l}\text { Starbucks gives a classy impression to } \\
\text { consumers }\end{array}$ & 0 & 0 & 0 & 0 & 0 & 0 & 25 & 25,0 & 75 & 75,0 \\
\hline
\end{tabular}

Based on the table above, it can be explained as follows: The first statement shows that one respondent answered that he disagreed about Starbucks as a well-known global coffee company, 38 respondents answered that they agreed that Starbucks is a globally renowned coffee company, and 61 respondents answered firmly that Starbucks is a worldrenowned coffee company. The second statement shows that 40 respondents answered that Starbucks has good coffee quality, and 60 respondents answered firmly that Starbucks has good quality coffee. The third statement shows that 25 respondents answered that Starbucks gives a classy impression to consumers, 75 respondents answered firmly about Starbucks giving an elegant appearance to consumers.

Table 4. Respondents' Responses Regarding Product Quality

\begin{tabular}{|c|c|c|c|c|c|c|c|c|c|c|}
\hline \multirow{3}{*}{ Statement } & \multicolumn{10}{|c|}{ Respondents' Answers } \\
\hline & \multicolumn{2}{|c|}{ STS } & \multicolumn{2}{|c|}{ TS } & \multicolumn{2}{|c|}{ KS } & \multicolumn{2}{|c|}{$\mathrm{S}$} & \multicolumn{2}{|c|}{ SS } \\
\hline & $\mathrm{N}$ & $\%$ & $\mathrm{~N}$ & $\%$ & $\mathrm{~N}$ & $\%$ & $\mathrm{~N}$ & $\%$ & $\mathrm{~N}$ & $\%$ \\
\hline $\begin{array}{l}\text { Starbucks products have form packaging } \\
\text { an attractive. }\end{array}$ & 0 & 0 & 0 & 0 & 1 & 1,0 & 42 & 42,0 & 57 & 57,0 \\
\hline $\begin{array}{l}\text { Starbucks products have extended product } \\
\text { durability. }\end{array}$ & 0 & 0 & 0 & 0 & 0 & 0 & 47 & 47,0 & 53 & 53,0 \\
\hline $\begin{array}{l}\text { Starbucks products have advantages over } \\
\text { other products. }\end{array}$ & 0 & 0 & 0 & 0 & 0 & 0 & 24 & 24,0 & 76 & 76,0 \\
\hline $\begin{array}{l}\text { Starbucks products have a style of } \\
\text { packaging that other products don't have. }\end{array}$ & 0 & 0 & 0 & 0 & 1 & 1,0 & 42 & 42,0 & 57 & 57,0 \\
\hline $\begin{array}{l}\text { Starbucks products have a distinctive } \\
\text { coffee taste. }\end{array}$ & 0 & 0 & 0 & 0 & 0 & 0 & 24 & 24,0 & 76 & 76,0 \\
\hline
\end{tabular}


Based on table 4, it can be explained as follows: The first statement shows that one respondent answered that he did not agree that Starbucks products had an attractive form of packaging, 42 respondents answered agreed that Starbucks products have a beautiful arrangement of packaging, and 57 respondents answered strongly agree about Starbucks products having an attractive packaging form. The second statement shows that 47 respondents answered agree that Starbucks products have extended product durability, and 53 respondents answered firmly that Starbucks products have extended product durability. The third statement shows that 24 respondents answered that Starbucks products have advantages over other products, and 76 respondents answered firmly that Starbucks products have advantages over other products. The fourth statement shows that one respondent answered disagree about the Starbucks product having a packaging style that other products do not have, 42 respondents answered that they agreed that the Starbucks product had a packaging style that other products did not have, 57 respondents responded that they decided that the Starbucks product had a packaging style that was not owned. Another product. The fifth statement shows that 24 respondents answered that the Starbucks product has a distinctive coffee taste, and 76 respondents answered firmly that the Starbucks product has a distinct coffee taste.

Table 5. Respondents' Responses Regarding Purchasing Decisions

\begin{tabular}{lcccccccccccc}
\hline \multirow{2}{*}{ Statement } & \multicolumn{10}{c}{ Respondents' Answers } \\
\cline { 2 - 12 } & \multicolumn{2}{c}{ STS } & \multicolumn{1}{c}{ TS } & \multicolumn{1}{c}{ KS } & S & \multicolumn{2}{c}{ SS } \\
\cline { 2 - 12 } & $\mathrm{N}$ & $\%$ & $\mathrm{~N}$ & $\%$ & $\mathrm{~N}$ & $\%$ & $\mathrm{~N}$ & $\%$ & $\mathrm{~N}$ & $\%$ \\
\hline $\begin{array}{l}\text { I bought Starbucks products because of } \\
\text { my desire. }\end{array}$ & 0 & 0 & 0 & 0 & 0 & 0 & 18 & 18,0 & 82 & 82,0 \\
$\begin{array}{l}\text { Friends/family } \\
\text { purchase coffee products at Starbucks. }\end{array}$ & 0 & 0 & 0 & 0 & 1 & 1,0 & 36 & 36,0 & 63 & 63,0 \\
$\begin{array}{l}\text { I made comparisons of other products } \\
\text { before purchasing a Starbucks product. }\end{array}$ & 0 & 0 & 0 & 0 & 0 & 0 & 34 & 34,0 & 66 & 66,0 \\
\hline
\end{tabular}

Based on the table 5, it can be explained as follows: The first statement shows that 18 respondents answered agree about buying Starbucks products because of their desires, and 82 respondents answered firmly about buying Starbucks products because of their desires. The second statement shows that one respondent answered disagree about friends/family recommending buying coffee products at Starbucks, 36 respondents answered agreeing about friends/family recommending buying coffee products at Starbucks, and 63 respondents answered strongly agree about friends/family suggesting to make purchases of coffee products at Starbucks. The third statement shows that 34 respondents answered agree about comparing other products before making a Starbucks product purchase, and 66 respondents answered firmly about comparing other products before making a Starbucks product purchase.

\subsection{Hypothesis Testing Results}

The validity test is used to measure whether a questionnaire is valid or not. A questionnaire is useful if the questionnaire questions can reveal everything that the questionnaire will measure. The validity test is calculated by comparing the computed $r$-value (correlation item-total correlation) with the $r$ table value. If $r$ count $>r$ table and the value is positive, then the question is declared valid. The test results are as follows:

Table 6. Test ResultsValidity

\begin{tabular}{ccccc}
\hline Variable & Item Questions & R Calculate & R Table & Description \\
\hline \multirow{3}{*}{ Brand Image (X1) } & ITEM 1 & 0,794 & 0,1946 & Valid \\
& ITEM 2 & 0,826 & 0,1946 & Valid \\
& ITEM 3 & 0,811 & 0,1946 & Valid \\
\hline \multirow{3}{*}{ Product Quality (X2) } & ITEM 1 & 0,809 & 0,1946 & Valid \\
& ITEM 2 & 0,745 & 0,1946 & Valid \\
& ITEM 3 & 0,758 & 0,1946 & Valid \\
& ITEM 4 & 0,809 & 0,1946 & Valid \\
& ITEM 5 & 0,758 & 0.1946 & Valid \\
\hline
\end{tabular}




\begin{tabular}{ccccc}
\hline Variable & Item Questions & R Calculate & R Table & Description \\
\hline \multirow{3}{*}{ Purchase Decision (Y) } & ITEM 1 & 0,808 & 0,1946 & Valid \\
& ITEM 2 & 0,730 & 0,1946 & Valid \\
& ITEM 3 & 0,729 & 0,1946 & Valid \\
\hline
\end{tabular}

Based on the validity test of the 11 statements in table 6 , it is known that all data have an $\mathrm{R}$ count greater than the $\mathrm{R}$ table, so all data is declared valid so that it can be used for further data processing.

Reliability test is data to measure a questionnaire which is an indicator of the variable. A questionnaire is reliable or reliable if someone's answer to a statement is consistent or stable over time. Reliability concerning the consistency of responses if tested repeatedly on different samples. SPSS provides facilities to measure reliability with the Cronbach Alpha (a) statistical test. A variable is said to be reliable if it gives a Cronbach Alpha value> 0.60 . Then the results of the test are as follows:

Table 7. Reliability Test Results

\begin{tabular}{ccc}
\hline Variables & Alpha & Description \\
\hline Brand Image (X1) & 0,735 & Reliable \\
Product Quality (X2) & 0,833 & Reliable \\
Purchase Decisions (Y) & 0,603 & Reliable
\end{tabular}

Based on the table 7, it can be seen that all variables are more significant than 0.60 , so that it is said to be reliable, meaning that the questionnaire can be used more than one time and is reliable. Multiple regression analysis is a study of the dependent variable's dependence (bound) with one or more independent variables (explanatory or independent variables) to estimate the population average or the average value of the dependent variable based on the known value of the independent variable. The results of multiple regression analysis are in the form of coefficients for each independent variable. This study's multiple regression analysis aims to determine the influence independent variable's influence (Brand Image and Product Quality) on the dependent variable (Purchase Decision). The results of multiple regression analysis are in the form of coefficients for each independent variable. This coefficient is obtained by predicting the value of the dependent variable with an equation.

Table 8. Results of Multiple Linear Regression Analysis

\begin{tabular}{|c|c|c|c|c|c|c|}
\hline \multicolumn{7}{|c|}{ Coefficients } \\
\hline & \multirow[t]{2}{*}{ Model } & \multicolumn{2}{|c|}{ Unstandardized Coefficients } & $\begin{array}{l}\text { Standardized } \\
\text { Coefficients }\end{array}$ & \multirow[t]{2}{*}{$\mathrm{t}$} & \multirow[t]{2}{*}{ Sig. } \\
\hline & & $\mathrm{B}$ & Std. Error & Beta & & \\
\hline \multirow{3}{*}{1} & (Constant) & 2.050 & 0.473 & & 4.339 & 0.000 \\
\hline & Brand Image & 0.296 & 0.076 & 0.336 & 3.919 & 0.000 \\
\hline & Product Quality & 0.342 & 0.047 & 0.618 & 7.217 & 0.000 \\
\hline
\end{tabular}

Based on the table 8 , it can be concluded that several variables can identify the purchasing decision variable, so it can be supposed that the equation is as follows:

$$
\mathrm{Y}=2.050+0.296(\mathrm{X} 1)+0.342(\mathrm{X} 2)+\mathrm{e}
$$

Based on the results of the regression equation, it can be explained that the influence of each independent variable on the dependent variable is as follows:

a) The constant value is 2.050, meaning that if the Brand Image (X1) and Product Quality (X2) are equal to zero, then the purchase decision is favorable. 
b) The regression coefficient value for the Brand Image variable (X1) is 0.296. This means that Brand Image has a positive effect on purchasing decisions.

c) The regression coefficient value for the Product Quality variable (X2) is 0.342 . This means that product quality has a positive effect on purchasing decisions.

d) The analysis results show that the independent or independent variable that has the most influence is Product Quality, with a coefficient of 0.342. In contrast, the variable that has the lowest influence is Brand Image with a coefficient of 0.296; from this equation, all independent variables have a positive effect on purchasing decisions.

The coefficient of determination measures the extent to which the independent variable explains the dependent variable. The following table of determination coefficients produced in this study (table 9).

Table 9. Results of the Coefficient of Determination

\begin{tabular}{ccccc}
\hline \multicolumn{4}{c}{ Model Summary } \\
\hline Model & $\mathrm{R}$ & R Square & Adjusted R Square & $\begin{array}{c}\text { Std. The error of the } \\
\text { Estimate }\end{array}$ \\
\hline 1 & $0.933^{\mathrm{a}}$ & 0.871 & 0.868 & 0.374 \\
\hline Predictors: (Constant), Product Quality, Brand Image & & \\
\hline
\end{tabular}

Based on the table 9, it can be seen that the magnitude of $\mathrm{R} 2$ is 0.871 , this means that $87.1 \%$ of the variation of e purchasing decisions can be explained by variations of the two independent variables, namely Brand Image (X1) and Product Quality (X2) while the rest $(100 \%)-87.1 \%=12.9 \%)$ explained by other causes that cannot be described in the regression equation or other factors not examined in this study. In this study, the F test was used to determine the significance level of the influence dependent variables influence (Ghozali, 2005). In this, the research hypothesis is as follows:

$\mathrm{H}_{0}=$ There is no influence of brand image and product quality on Starbucks Trans Studio Mall Makassar's purchasing decisions.

$\mathrm{H}_{1}=$ There is an influence of brand image and product quality on Starbucks Trans Studio Mall Makassar's purchasing decisions.

The results of the calculation of the F test are as follows in table 10.

Table 10. Simultaneous Significant Test Results (F statistical test)

\begin{tabular}{|c|c|c|c|c|c|c|}
\hline \multicolumn{7}{|c|}{ ANOVA } \\
\hline Model & & Sum of Squares & $\mathrm{df}$ & Mean Square & $\mathrm{F}$ & Sig. \\
\hline & Regression & 91.448 & 2 & 45.724 & 327.285 & $0.000^{\mathrm{b}}$ \\
\hline 1 & Residual & 13.552 & 97 & 0.140 & & \\
\hline & Total & 105.000 & 99 & & & \\
\hline
\end{tabular}

a. Dependent Variable: Keputusan Pembelian

b. Predictors: (Constant), Product Quality, Brand Image

Based on the table 10, the ANOVA test or the F statistical test, the calculated F value is 327.285 with a probability level of 0.000 . The probability is smaller than 0.05 , so $\mathrm{H} 0$ is rejected, and $\mathrm{H} 1$ is accepted that there is a significant influence between brand image and product quality variables on purchasing decisions at Starbucks Trans Studio Mall Makassar. The t-test is used for a test aimed at whether or not each regression coefficient is significant or not on the independent variables. Or the t-test to find out whether the independent variable has a significant effect on the dependent variable.

The t-test in the table 11 can be used to determine whether the independent variable significantly affects the dependent variable. The following describes the results of the calculation of the t-test for each variable: The results of the partial effect significance test (t-test) on the Brand Image variable resulted in a significance of 0.000 . The 
significance level of 0.000 is less than 0.05 , so it can be seen that the hypothesis which states that Brand Image affects purchasing decisions is acceptable. The partial effect significance test (t-test) of the product quality variable resulted in a significance of 0.000 . The significance level of 0.000 is less than 0.05 , so it can be seen that the hypothesis which states that product quality affects purchasing decisions is acceptable.

Table 11. Significant Test Results Partial Effect (t-test)

\begin{tabular}{|c|c|c|c|c|c|c|}
\hline \multicolumn{7}{|c|}{ Coefficients } \\
\hline & \multirow{2}{*}{ Model } & \multicolumn{2}{|c|}{ Unstandardized Coefficients } & $\begin{array}{l}\text { Standardized } \\
\text { Coefficients }\end{array}$ & \multirow[t]{2}{*}{$\mathrm{t}$} & \multirow[t]{2}{*}{ Sig. } \\
\hline & & B & Std. Error & Beta & & \\
\hline \multirow{3}{*}{1} & (Constant) & 2.050 & 0.473 & & 4.339 & 0.000 \\
\hline & Brand Image & 0.296 & 0.076 & 0.336 & 3.919 & 0.000 \\
\hline & Product Quality & 0.342 & 0.047 & 0.618 & 7.217 & 0.000 \\
\hline
\end{tabular}

a. Dependent Variable: Purchase Decision

\subsection{Discussion of Research Results}

Multiple linear regression analysis aims to determine the effect of brand image and product quality on purchasing decisions with SPSS obtained by the equation $\mathrm{Y}=2.050+0.296(\mathrm{X} 1)+0.342(\mathrm{X} 2)+\mathrm{e}$, stating that if there is a brand image (X1) and Product quality (X2) is considered constant, so the purchase decision will be equal to 2.050 and 0.296 states that every addition of one brand image point (X1) will increase the purchase decision (Y) by 0.296. Meanwhile, 0.342 states that each addition of one product quality point (X2) will increase the visiting decision (Y) by 0.342 . Ttest to determine the effect of Brand Image and Product Quality on purchasing decisions. Calculations using the SPSS program, the testing criteria is $\mathrm{H} 1$ accepted if the significant level $\mathrm{t}$-count $>\mathrm{t}$-table $=0.05$. Based on testing the first hypothesis, the t-count value was 3,919. The decision to test $\mathrm{H} 1$ was accepted because $\mathrm{t}$-count $>\mathrm{t}$-table, namely, 3.919 $>1.983$, and the significance probability value $<0.05$, namely 0.000 . In conclusion, there is a significant influence between the brand image on purchasing decisions and testing the second hypothesis, and it is known that the t-table is 7,217. The decision to test $\mathrm{H} 1$ was accepted because the t-calculated > t-estimated was 7,217>1,983, and the probability value of significance $<0.05$ was 0,000 . The conclusion is that there is a significant influence between product quality on purchasing decisions. The analysis results show that the significance value is $0.000<0.05$ so that the brand image has a positive and significant effect on purchasing decisions. It can be said that the better the brand image, the higher the purchasing decision. Conversely, the worse the brand image, the lower the purchasing decision. The analysis results show that the significance value is $0.000<0.05$, so that the product quality has a positive and significant effect on purchasing decisions. Then the higher the product quality, the higher the purchasing decision. Conversely, the lower the product quality, the lower the purchasing decision. The research results obtained are based on the F test of 327.285 with a probability level of $0.000<0.05$. The variables brand image and product quality have a significant effect on purchasing decisions. This shows a high level of purchasing decisions when a good brand image and good quality products are offered to consumers. The t-test analysis results show that the product quality variable has a greater influence on purchasing decisions than the brand image variable; this means that the good quality of the product offered to Starbucks consumers has more influence than the brand image variable. This research is also in line with previous research conducted by Purwati (2012). The variables used in this study were purchasing decisions as to the dependent variable, while the independent variables used were brand image, product quality, and price.

\section{Conclusion}

Based on the descriptions and research results that have been stated previously, it can be concluded that the Brand Image has a positive and significant effect on purchasing decisions at Starbucks Trans Studio Mall Makassar. It can be supposed that if the brand image variable is increased, consumer purchasing decisions will also increase. Also, product quality has a positive and significant effect on Starbucks Trans Studio Mall Makassar's purchasing decisions. It can be concluded that if the variable product quality is increased, consumer purchasing decisions will also increase. The uneven quality of the product is the most dominant variable influence on purchase decisions at Starbucks Trans Studio Mall Makassar. Based on the results of research and discussion on the influence of brand image and product quality on purchasing decisions at Starbucks Trans Studio Mall Makassar, then put forward suggestions as a 
complement to the research results as following: The results showed that the brand image variable gave positive and significant effects on purchasing decisions, this indicated that Starbucks should maintain a good brand reputation which would increase consumer loyalty. Introducing products to consumers will give a good impression, and consumers will also remember the product. The results showed that the product quality variable had positive and significant consequences on purchasing decisions; this indicated that Starbucks had to improve the quality of the products offered to increase sales levels. $12.9 \%$ of variables are not examined in this thesis, and this also affects the purchasing decision at Starbucks Trans Studio Mall Makassar, the variables that are not examined are (Price, Location, and Lifestyle). Researched, so you can find out what variables influence a person to make purchasing decisions at Starbucks Trans Studio Mall Makassar.

\section{References}

Field, A., Miles, J., \& Field, Z. (2013). Discovering Statistics Using SPSS. In Sage (Vol. 81, Issue 1). https://doi.org/10.1111/insr.12011_21

Garson, G. D. (2016). Partial Least Squares: Regression and Structural Equation Models. Statistical Associates Publishers. https://doi.org/ISBN-13: 978-1-62638-039-4

Ghozali, I. (2013). Aplikasi Analisis Multivariate Dengan Program IBM dan SPSS. In aplikasi analisis multivariate dengan program ibm spss 19 (p. 113). https://doi.org/10.2307/1579941

Halkias, G., Micevski, M., Diamantopoulos, A., \& Milchram, C. (2017). Exploring the effectiveness of foreign brand communication: Consumer culture ad imagery and brand schema incongruity. Journal of Business Research, 80(March), 210-217. https://doi.org/10.1016/j.jbusres.2017.04.018

Huang, Y. C., \& Liu, C. H. (2020). Buffering effects of brand perception to behavioural intention - Evidence of China airlines. Research in Transportation Business and Management, November 2019. https://doi.org/10.1016/j.rtbm.2020.100468

Kim, S.-H., \& Yoo, B.-K. (2015). Analysis of the Factors Affecting Customer Satisfaction and Customer Loyalty in a Family Restaurant Chain* 체인 패밀리 레스토랑의 고객 만족 및 고객 충성도에 미치는 요인 분석. Journal of Distribution Science, 13(5), 103-111. https://doi.org/10.15722/jds.13.5.201505.103

Kotler, P., Wong, V., Saunders, A. J., \& Armstrong, G. (2013). Principles Of Marketing. In Pearson education (Vol. 53, Issue 9). https://doi.org/10.1017/CBO9781107415324.004

Lee, C., Lee, K., \& Pennings, J. M. (2001). Internal capabilities, external networks, and performance: A study on technology-based ventures. Strategic Management Journal, 22(6-7), 615-640. https://doi.org/10.1002/smj.181

Ma, J., Yang, J., \& Yoo, B. (2020). The moderating role of personal cultural values on consumer ethnocentrism in developing countries: The case of Brazil and Russia. Journal of Business Research, 108(December 2019), 375389. https://doi.org/10.1016/j.jbusres.2019.12.031

Maheshwari, S., \& Yadav, R. S. (2015). Is CSR a Hygiene Factor for Prospective Employees? An Indian Exploration. In Indian Journal of Industrial Relations (Vol. 50, pp. 601-612). Shri Ram Centre for Industrial Relations and Human Resources. https://doi.org/10.2307/24547007

Ramlawati, Putra, A. H. P. K., Yasni, Basalamah, J., \& Mappatompo, A. (2019, July). Why Millenials Eat Out From Home? BT - 1st International Conference on Life, Innovation, Change and Knowledge (ICLICK 2018). https://www.atlantis-press.com/article/125913306

Rudolph, C. W., Zacher, H., \& Hirschi, A. (2019). Empirical developments in career construction theory. Journal of Vocational Behavior, 111, 1-6. https://doi.org/https://doi.org/10.1016/j.jvb.2018.12.003

Sondakh, C. (2015). Kualitas Layanan, Citra Merek Dan Pengaruhnya Terhadap Kepuasan Nasabah Dan Loyalitas Nasabah Tabungan (Studi Pada Nasabah Taplus BNI Cabang Manado). Jurnal Riset Bisnis Dan Manajemen, 
$3(1), 19-32$.

Sugiyono. (2014). Metode Penelitian Pendidikan Pendekatan Kuantitatif, Kualitatif dan R\&D. In Metode Penelitian Pendidikan Pendekatan Kuantitatif, Kualitatif Dan R\&D. https://doi.org/10.1007/s13398-014-0173-7.2

Yoon C. Cho, E. S. (2015). Exploring Factors That Affect Usefulness, Ease Of Use, Trust, And Purchase Intention In The Online Environment. International Journal of Management \& Information Systems, 19(1), 21-56.

Zhu, D. H., Deng, Z. Z., \& Chang, Y. P. (2020). Understanding the influence of submission devices on online consumer reviews:A comparison between smartphones and PCs. Journal of Retailing and Consumer Services, 54(June 2019), 102028. https://doi.org/10.1016/j.jretconser.2019.102028 